\title{
Faktor yang Berhubungan dengan Kejadian Balita Stunting Usia 24-36 Bulan Tahun 2018
}

\section{Factor Associated with the Incidence of Stunting Toddlers Ages 24-36 Months In 2018}

\author{
Nurul Aryastuti ${ }^{1}$, Yuyun Kamsiati², Dainty Maternity ${ }^{3}$ \\ ${ }^{1}$ Fakultas Kesehatan Masyarakat Universitas Malahayati, Lampung, Indonesia \\ 2 Puskesmas Banjar Agung, Lampung Selatan, Indonesia \\ ${ }^{3}$ Fakultas Kedokteran Universitas Malahayati, Lampung, Indonesia \\ *Korespondensi penulis: nurularyastuti@gmail.com
}

Penyerahan: 15-05-2020, Perbaikan: 24-07-2020, Diterima: 23-08-2020

\begin{abstract}
Stunting is defined as height according to age below the median -2 standard of the child growth curve of WHO. The stunting number of South Lampung Regency in 2017 reached 30.3\%. At the Banjar Agung Public Health Center in 2017, 31 children were stunted. The study aimed to determine the factors associated with stunting of children aged 24-36 months. This research was quantitative with a cross-sectional approach. Data collection were used by taking direct measurements and looking at KIA books. The population were toddlers aged 24-36 months in Banjar Agung Public Health Center South Lampung Regency in the amount of 474 toddlers. The sample of 362 respondents with proportional random sampling technique. Data were analyzed using chi-square test and multiple logistic regression tests. The results showed that the stunting rate of infants aged 24-36 months was $26 \%$. There was the relationship between the history of chronic energy deficiency in the mother ( $p<0.001$, OR 16.1, 95\% CI 5.9-43.9), maternal height ( $p<0.001$, OR 12.9, 95\%CI 3.6-46.9), maternal age at pregnancy ( $p$ 0.038, OR 2.8, 95\%CI 1.1-6.8), LBW history ( $p<0.001$, OR 14.1, 95\%CI 2.9-66.4), history of non-exclusive breastfeeding ( $p$ $<0.001$, OR 9.5, 95\%CI 5.5-16.3) and clean water supplies that do not meet the requirements ( $p<0.001$, OR 8.9, 95\%CI 5.3-15.3). The most dominant factor was a history of chronic energy deficiency in the mother during pregnancy (OR 12.6, 95\%CI 3.9-40.8). It was recommended that Puskesmas treatment stunting toddlers cooperate with cross-sectors related to making commitments that support the policy of delaying marriage age $<20$ years, applying exclusive breastfeeding, improving environmental sanitation and increasing access to clean water for the community.
\end{abstract}

Keywords: Stunting, Maternal Factors, exclusive breastfeeding, Clean Water Supply.

\section{ABSTRAK}

Stunting didefinisikan sebagai tinggi badan menurut usia dibawah -2 standar median kurva pertumbuhan anak WHO (WHO, 2010). Angka stunting Kabupaten Lampung Selatan tahun 2017 mencapai 30,3 \%. Di Puskesmas Banjar Agung tahun 2017 didapatkan 31 balita mengalami stunting. Tujuan penelitian untuk mengetahui faktor yang berhubungan dengan stunting balita usia 24-36 bulan. Penelitian ini kuantitatif dengan pendekatan cross sectional. Pengumpulan data dengan melakukan pengukuran langsung dan melihat buku

Jurnal Dunia Kesmas, Vol. 9 No. 3, Juli 2020, hal. 336-345 
KIA. Populasi adalah balita berusia 24-36 bulan di Puskesmas Banjar Agung sejumlah 474 balita, sampel 362 responden dengan teknik proporsional random sampling. Analisa data univariat dengan distribusi frekuensi, bivariat dengan uji chi square dan multivariat dengan uji regresi logistik ganda. Hasil penelitian menunjukkan angka stunting balita usia 24-36 bulan sebesar $26 \%$. Ada hubungan antara riwayat kurang energi kronis pada ibu $(p<0.001$, OR 16.1, 95\% CI 5.9-43.9), tinggi badan ibu ( $p<0.001$, OR 12.9, 95\%CI 3.6-46.9), usia ibu saat hamil ( $p$ 0.038, OR 2.8, 95\%CI 1.1-6.8), riwayat BBLR ( $<<0.001$, OR 14.1, 95\%CI 2.9-66.4), riwayat ASI tidak Ekslusif ( $p<0.001$, OR 9.5, 95\%CI 5.5-16.3) dan persediaan air bersih yang tidak memenuhi syarat ( $p<0.001$, OR 8.9, 95\%CI 5.3-15.3). Faktor paling dominan adalah riwayat kurang energi kronis pada ibu saat hamil (OR 12.6, 95\% CI 3.940.8). Disarankan agar Puskesmas melakukan penanganan terhadap balita stunting, bekerja sama dengan lintas sektor terkait membuat komitmen yang mendukung kebijakan penundaan usia perkawinan <20 tahun, penerapan ASI ekslusif, perbaikan sanitasi lingkungan dan peningkatan akses air bersih bagi masyarakat.

Kata kunci: Stunting, Faktor Maternal, ASI ekslusif, Persediaan Air Bersih.

\section{PENDAHULUAN}

Balita pendek adalah balita dengan status gizi yang berdasarkan panjang atau tinggi badan menurut umurnya bila dibandingkan dengan standar baku WHO-MGRS (Multicentre Growth Reference Study) tahun 2005, nilai zscorenya kurang dari -2SD dan dikategorikan sangat pendek jika nilai z-scorenya kurang dari -3 SD (Kemenkes RI, 2016). Stunting pada masa anak-anak berdampak pada tinggi badan yang pendek dan penurunan pendapatan saat dewasa, rendahnya angka masuk sekolah, dan penurunan berat lahir keturunannya kelak (Victora et al., 2008). Trihono dkk (2015) memaparkan analisis korelasi data agregat tiap kabupaten/kota hasil Riskesdas 2013 dari indikator IPKM 2013 bahwa status gizi pendek pada balita dan anak usia sekolah dipengaruhi oleh faktor kesehatan lingkungan, pelayanan kesehatan, perilaku penduduk, kesehatan reproduksi, status ekonomi dan status pendidikan. Kabupaten Lampung Selatan masuk dalam kategori wilayah dengan prevalensi pendek tinggi sebesar
30,3 \%. Pendataan awal balita stunting umur 24-36 bulan di wilayah kerja Puskesmas Banjar Agung Kabupaten Lampung Selatan tahun 2017 terdapat 31 balita yang masuk dalam kategori stunting dan belum pernah diadakan penelitian faktor faktor yang berhubungan dengan kejadian balita stunting sebelumnya. Berdasarkan uraian di latar belakang peneliti tertarik untuk meneliti lebih jauh Faktor yang berhubungan dengan kejadian stunting pada balita usia 24-36 bulan di wilayah kerja Puskesmas Banjar Agung Kabupaten Lampung Selatan Tahun 2018.

\section{METODE}

Jenis penelitian yang digunakan adalah kuantitatif dengan desain cross sectional. Penelitian dilakukan di wilayah kerja Puskesmas Banjar Agung Kabupaten Lampung Selatan pada bulan Oktober sampai dengan November 2018. Populasi dalam penelitian ini adalah seluruh balita 2436 bulan di wilayah kerja Puskesmas Banjar Agung yaitu 474 orang. Jumlah sampel dalam penelitian ini adalah 362 orang dengan teknik proportional 
random Sampling. Variabel independen dalam penelitian ini adalah kurang energi kronis pada ibu, tinggi badan ibu, usia ibu saat hamil, riwayat berat badan lahir rendah, jarak kelahiran, riwayat hipertensi, riwayat pemberian ASI Ekslusif dan persediaan air bersih. Variabel dependen dalam penelitian ini adalah stunting pada balita 24-36 bulan. Analisis data menggunakan Chi square dan regresi logistik ganda.

\section{HASIL}

Berdasarkan tabel 1 didapatkan hasil bahwa sebanyak $26 \%$ balita $24-36$ bulan mengalami stunting. Sebesar $7,5 \%$ ibu memiliki riwayat KEK saat hamil, sebanyak $4,1 \%$ ibu memiliki tinggi badan pendek, 5,8\% ibu hamil berusia kurang atau sama dengan 19 tahun, sebanyak $3 \%$ anak memiliki riwayat BBLR, sebanyak 2,5\% mempunyai jarak kelahiran kurang dari 2 tahun, sebanyak 2,5\% ibu memiliki riwayat hipertensi, sebanyak $36,7 \%$ anak mempunyai riwayat ASI tidak ASI Ekslusif dan 28,7\% mempunyai persediaan air bersih yang tidak memenuhi syarat.
Tabel 1. Distribusi Karakteristik Responden

\begin{tabular}{|c|c|c|}
\hline Variabel & Jumlah & $\%$ \\
\hline \multicolumn{3}{|l|}{ Tinggi badan anak } \\
\hline Stunting & 94 & 26 \\
\hline Tidak Stunting & 268 & 74 \\
\hline \multicolumn{3}{|l|}{ KEK pada ibu } \\
\hline KEK & 27 & 7,5 \\
\hline Tidak KEK & 335 & 92,5 \\
\hline \multicolumn{3}{|l|}{ Tinggi badan ibu } \\
\hline Pendek & 15 & 4,1 \\
\hline Tidak pendek & 347 & 95,9 \\
\hline \multicolumn{3}{|l|}{ Usia ibu saat hamil } \\
\hline$\leq 19$ tahun & 21 & 5,8 \\
\hline > 19 tahun & 341 & 94,2 \\
\hline \multicolumn{3}{|l|}{ Riwayat BBLR } \\
\hline BBLR & 11 & 3 \\
\hline Tidak BBLR & 351 & 97 \\
\hline \multicolumn{3}{|l|}{ Jarak Kelahiran } \\
\hline$<2$ tahun & 9 & 2,5 \\
\hline$\geq 2$ tahun & 353 & 97,5 \\
\hline \multicolumn{3}{|l|}{ Riwayat hipertensi } \\
\hline Hipertensi & 9 & 2,5 \\
\hline Tidak hipertensi & 353 & 97,5 \\
\hline \multicolumn{3}{|l|}{ Riwayat ASI } \\
\hline Tidak ekslusif & 133 & 36,7 \\
\hline Ekslusif & 229 & 63,3 \\
\hline \multicolumn{3}{|c|}{ Persediaan air bersih } \\
\hline $\begin{array}{l}\text { Tidak memenuhi } \\
\text { Syarat }\end{array}$ & 104 & 28,7 \\
\hline Memenuhi syarat & 258 & 71,3 \\
\hline
\end{tabular}

Tabel 2. Model Bivariat Kejadian Stunting Balita 24 - 36 Bulan Tinggi Badan Anak \begin{tabular}{lcccc} 
tidak & total & OR & $\begin{array}{c}P \text { - } \\
\text { value }\end{array}$ \\
\cline { 1 - 2 } & stunting
\end{tabular} v

KEK pada ibu

$\begin{array}{lllllll}\text { N } & \% & \text { N } & \% & \text { N } & \% & (95 \% \mathrm{CI})\end{array}$

$\begin{array}{llllllll}\mathrm{N} & \% & \mathrm{~N} & \% & \mathrm{~N} & \% & (95 \% \mathrm{Cl})\end{array}$

\begin{tabular}{|c|c|c|c|c|c|c|c|c|}
\hline KEK & 22 & 81,5 & 5 & 18,5 & 27 & 100 & 16,072 & $<0,001$ \\
\hline $\begin{array}{l}\text { Tidak KEK } \\
\text { Tingi }\end{array}$ & 72 & 21,5 & 263 & 78,5 & 335 & 100 & $5,881-43,926$ & \\
\hline \multicolumn{9}{|c|}{ Tinggi badan ibu } \\
\hline Pendek & 12 & 80 & 3 & 20 & 15 & 100 & 12,927 & $<0,001$ \\
\hline Tidak pendek & 82 & 23,6 & 265 & 76,4 & 347 & 100 & $3,561-46,921$ & \\
\hline \multicolumn{9}{|c|}{ Usia ibu saat hamil } \\
\hline$\leq 19$ tahun & 10 & 47,6 & 11 & 52,4 & 21 & 100 & 2,781 & 0,038 \\
\hline$>19$ tahun & 84 & 24,6 & 257 & 75,4 & 341 & 100 & $1,141-6,780$ & \\
\hline
\end{tabular}

Jurnal Dunia Kesmas, Vol. 9 No. 3, Juli 2020, hal. 336-345 


\begin{tabular}{|c|c|c|c|c|c|c|c|c|}
\hline \multirow[b]{3}{*}{ Variabel } & \multicolumn{4}{|c|}{ Tinggi Badan Anak } & \multirow{2}{*}{\multicolumn{2}{|c|}{ total }} & \multirow{3}{*}{$\begin{array}{c}\text { OR } \\
(95 \% \mathrm{CI})\end{array}$} & \multirow{3}{*}{$\begin{array}{c}\text { P- } \\
\text { value }\end{array}$} \\
\hline & \multicolumn{2}{|c|}{ Stunting } & \multicolumn{2}{|c|}{$\begin{array}{c}\text { tidak } \\
\text { stunting }\end{array}$} & & & & \\
\hline & $\mathbf{N}$ & $\%$ & $\mathbf{N}$ & $\%$ & $\mathbf{N}$ & $\%$ & & \\
\hline \multicolumn{9}{|l|}{ Riwayat BBLR } \\
\hline BBLR & 9 & 81,8 & 2 & 18,2 & 11 & 100 & 14,082 & $<0,001$ \\
\hline Tidak BBLR & 85 & 24,2 & 266 & 75,8 & 351 & 100 & $2,984-66,449$ & \\
\hline \multicolumn{9}{|l|}{ Jarak Kelahiran } \\
\hline$<2$ tahun & 5 & 55,6 & 4 & 44,4 & 9 & 100 & 3,708 & 0,055 \\
\hline$\geq 2$ tahun & 89 & 25,6 & 264 & 74,8 & 353 & 100 & $0,974-14,112$ & \\
\hline \multicolumn{9}{|l|}{ Riwayat hipertensi } \\
\hline Hipertensi & 5 & 55,6 & 4 & 44,4 & 9 & 100 & 3,708 & 0,055 \\
\hline Tidak hipertensi & 89 & 25,2 & 264 & 74,8 & 353 & 100 & $0,974-14,112$ & \\
\hline \multicolumn{9}{|l|}{ Riwayat ASI } \\
\hline Tidak ekslusif & 70 & 52,6 & 65 & 47,4 & 133 & 100 & 9,491 & $<0,001$ \\
\hline Ekslusif & 24 & 10,5 & 205 & 89,5 & 229 & 100 & $5,515-16,332$ & \\
\hline \multicolumn{9}{|l|}{$\begin{array}{l}\text { Persediaan air } \\
\text { bersih }\end{array}$} \\
\hline Tdk memenuhi syarat & 60 & 57,7 & 44 & 42,3 & 104 & 100 & 8,984 & $<0,001$ \\
\hline Memenuhi syarat & 34 & 13,2 & 224 & 86,8 & 258 & 100 & $5,285-15,271$ & \\
\hline
\end{tabular}

Tabel 3. Model Multivariat Kejadian Balita Stunting Usia 24-36 Bulan

\begin{tabular}{lccrrr}
\hline \multicolumn{1}{c}{ Variabel } & Koefisien & $\boldsymbol{p}$ & OR & \multicolumn{2}{c}{ CI 95\% } \\
\cline { 5 - 6 } & Beta & & & Min & Maks \\
\hline Kek pada ibu & 2,530 & 0,000 & 12,550 & 3,861 & 40,796 \\
Tinggi badan ibu & 2,515 & 0,001 & 12,369 & 2,655 & 57,636 \\
Riwayat BBLR & 2,248 & 0,016 & 9,468 & 1,529 & 58,629 \\
Riwayat ASI & 1,404 & 0,000 & 4,070 & 2,078 & 7,971 \\
$\begin{array}{l}\text { Persediaan air } \\
\text { bersih }\end{array}$ & 1,731 & 0,000 & 5,645 & 2,898 & 10,996 \\
Riwayat hipertensi & 0,469 & 0,600 & 1,598 & 0,277 & 9,213 \\
$\begin{array}{l}\text { Usia ibu saat } \\
\text { hamil }\end{array}$ & $-0,353$ & 0,531 & 0,702 & 0,232 & 2,123 \\
\hline
\end{tabular}

Berdasarkan model multivariat tahap akhir diatas ternyata variabel yang berhubungan bermakna dengan kejadian stunting adalah variabel KEK pada ibu, tinggi badan ibu, riwayat $B B L R$, riwayat pemberian ASI, dan persediaan air bersih, sedangkan variabel riwayat hipertensi dan usia ibu saat hamil sebagai variabel confounding. Hasil analisis Odds Ratio (OR) dari variabel KEK pada ibu adalah 12,550 (95\%CI 3,861-40,796) dengan nilai $p$ value sebesar 0,00 ( $p$ $\leq 0,05)$. Tidak ada interaksi antar variabel yang artinya bahwa variabel variabel tersebut mempunyai peran sendiri- sendiri dengan kejadian stunting. Dapat dijelaskan ibu yang 
memiliki riwayat KEK saat hamil akan berpeluang mempunyai balita stunting sebesar 12,5 kali lebih tinggi dibandingkan dengan ibu tidak KEK, setelah dikontrol dengan variabel tinggi badan ibu, riwayat BBLR, riwayat pemberian ASI dan persediaan air bersih.

\section{PEMBAHASAN}

Malina (2012) dalam Fikawati dkk (2017) menyatakan pertumbuhan manusia merupakan hasil interaksi antara faktor genetik, hormon, zat gizi dan energi dengan faktor lingkungan. Asupan energi dan protein yang tidak mencukupi pada ibu hamil dapat memyebabkan kurang energi kronis (KEK). Buruknya gizi selama kehamilan, masa pertumbuhan dan masa awal kehidupan anak dapat menyebabkan anak menjadi stunting (Dewey \& Begum, 2010). Hasil penelitian ini sejalan dengan penelitian Sartono (2016) tentang hubungan kurang energi kronis ibu hamil dengan kejadian stunting pada anak usia 6-24 bulan di kota Yogyakarta. Peneliti berpendapat bahwa tingginya ibu yang mempunyai riwayat KEK saat hamil dengan kejadian balita stunting bisa disebabkan karena ibu dengan KEK tidak mempunyai asupan gizi yang baik sebelum hamil, serta selama kehamilannya. Asupan gizi ibu saat hamil sangat penting karena faktanya dari hasil penelitian ini juga didapat 72 balita stunting memiliki ibu dengan riwayat tidak KEK. Menurut peneliti, diperlukan pemantauan untuk semua ibu hamil, baik yang KEK maupun tidak KEK dalam hal pemenuhan asupan gizi yang tepat dan seimbang sehingga diharapkan

Jurnal Dunia Kesmas, Vol. 9 No. 3, Juli 2020, hal. 336-345 ISSN 2301-6604 (Print), ISSN 2549-3485 (Online) http://ejurnalmalahayati.ac.id/index.php/duniakesmas/index pertumbuhan janin optimal sejak dalam kandungan.

Hasil penelitian Svepors P., at al (2016), Oktarina dan Sudiarti (2013) bahwa ada hubungan yang bermakna antara tinggi badan ibu dimana anak yang lahir dari ibu yang pendek mempunyai peluang sebesar 2,93 kali dan 1,36 kali mengalami stunting dibandingkan dengan anak yang lahir dari ibu yang tinggi badan normal. Berdasarkan data penelitian terdapat 12 orang $(80 \%)$ ibu pendek memiliki balita stunting, dan ada 82 orang $(23,6 \%)$ ibu tidak pendek mempunyai balita stunting. Peneliti berpendapat pada ibu yang pendek, Ibu mempunyai peluang untuk melahirkan dengan penyulit karena kemungkinan panggul sempit sehingga meningkatkan tindakan sectio caesaria, dan mungkin juga terjadi kelahiran dengan berat badan bayi yang rendah. Tetapi faktanya terdapat juga ibu yang tidak pendek namun memiliki balita stunting, hal ini kemungkinan disebabkan oleh ada hubungan faktor lain seperti KEK pada ibu, BBLR, ASI tdak ekslusif, persediaan air bersih dan terdapat faktor yang belum diteliti seperti faktor infeksi yang sering terjadi pada balita dan faktor asupan gizi balita baik dari segi jumlah, jenis dan waktu pemberiannya. Berdasarkan hasil penelitian ini peneliti berpendapat bahwa ada hubungan yang bermakna antara tinggi badan ibu pendek dengan kejadian stunting pada balita usia 24-36 bulan di wilayah kerja Puskesmas Banjar Agung tahun 2018.

Kehamilan pada usia remaja memiliki risiko lebih tinggi dibandingkan dengan kehamilan wanita diatas 20 
tahun. Kehamilan pada usia remaja memiliki peluang yang lebih besar untuk melahirkan bayi prematur atau bayi dengan berat badan lahir rendah. Kehamilan pada usia remaja merupakan salah satu penyebab secara tidak langsung kejadian stunting pada anak (Irwansyah, 2016). Penyulit pada kehamilan remaja lebih tinggi dibandingkan dengan kurun waktu reproduksi sehat antara 20-30 tahun. Hal ini disebabkan belum matangnya alat reproduksi untuk hamil, sehingga dapat merugikan kesehatan ibu maupun perkembangan dan pertumbuhan janin. Berdasarkan data penelitian yang didapat, dari 21 orang ibu yang hamil saat usia $\leq 19$ tahun terdapat 10 orang $(47,6 \%)$ yang memiliki balita stunting dan 11 orang $(52,4 \%)$ tidak memiliki balita stunting. Peneliti berpendapat selain usia, terdapat faktor lain yang berkontribusi seperti riwayat KEK, riwayat ASI ekslusif, persediaan air bersih, tinggi badan ibu dan BBLR serta faktor lain yang belum diteliti dalam penelitian ini seperti penyakit infeksi yang sering terjadi pada balita, Asupan gizi saat hamil, asupan gizi balita dan faktor pengetahuan ibu hamil, serta pengetahuan ibu dalam pola asuh terhadap bayi balita. Dalam penelitian ini terdapat hubungan yang bermakna antara usia ibu $\leq 19$ tahun dengan kejadian stunting pada balita usia 24-36 bulan di wilayah kerja Puskesmas Banjar Agung tahun 2018.

Hambatan pertumbuhan di masa awal kehidupan tidak hanya berkorelasi dengan tinggi badan yang pendek saat dewasa tetapi juga dengan gangguan metabolisme dan penyakit kronis tertentu. Hal ini sejalan dengan penelitian Ergin F at al (2007) bahwa BBLR akan meningkatkan risiko kejadian stunting sebesar 2,5 kali. Data Maternal and Child Undernutrition Study Grup oleh Victora et al (2008) mengindikasikan bahwa berat lahir yang rendah sangat berkorelasi dengan panjang badan lahir dan gizi kurang saat masa anakanak merupakan faktor risiko terhadap tingginya konsentrasi glukosa, tekanan darah, kandungan lemak berbahaya saat dewasa setelah dikontrol dengan faktor IMT juga tinggi badan saat dewasa (Fikawati dkk., 2017). Menurut podja \& Kelley (2000) dalam Fitri (2012) Bayi dengan berat lahir rendah memiliki risiko tinggi terhadap morbiditas, kematian, penyakit infeksi, kekurangan berat badan, stunting di awal periode neonatal sampai masa kanak-kanak. Berdasarkan hasil penelitian dari 11 balita yang mempunyai riwayat BBLR terdapat 9 balita $(81,8 \%)$ yang mengalami stunting, dan terdapat 2 balita $(19,2 \%)$ yang memiliki riwayat BBLR tidak mengalami stunting. Faktanya dari 9 balita yang mengalami stunting, terdapat faktor lain seperti 1 balita dengan faktor ASI tidak ekslusif, 3 balita memiliki faktor lain yaitu riwayat ASI tidak ekslusif dan persediaan air bersih yang tidak memenuhi syarat, 2 balita memiliki faktor ASI tidak ekslusif dan riwayat hipertensi, 3 balita memiliki faktor lain seperti jarak kelahiran yang dekat, ibu dengan riwayat hipertensi, tidak mendapat ASI ekslusif dan persediaan air yang tidak memenuhi syarat. Peneliti berpendapat bahwa balita yang mengalami BBLR akan sulit dalam mengejar ketertinggalan pertumbuhannya, terlebih bila balita 
tersebut mempunyai faktor lain yang dapat menghambat pertumbuhan dan perkembangannya. Bayi dengan BBLR harus mendapatkan penanganan dan pemantauan tumbuh kembang secara berkesinambungan agar tumbuh kembangnya optimal. Diperlukan perhatian dari semua pihak baik dari Puskesmas melalui Bidan desa dan petugas gizi agar melakukan pemantauan secara berkesinambungan, maupun dengan aparat desa dalam menjamin persediaan air bersih yang memenuhi syarat, dan sehingga bayi dengan BBLR dapat tumbuh optimal dan tidak berkembang menjadi stunting. Peneliti berpendapat bahwa asupan gizi ibu selama hamil dan menyusui, praktik pengasuhan yang tepat terhadap bayi dan balita seperti pemberian ASI ekslusif, pemberian makanan pendamping ASI tepat waktu serta jumlahnya, dan juga pencegahan terhadap penyakit infeksi berulang merupakan upaya yang dapat dilakukan untuk menghindari balita menjadi stunting.

Hasil penelitian Irwansyah (2016) yang menyatakan jarak kelahiran secara statistik dan praktis tidak menunjukkan hubungan yang bermakna. Menurut pendapat peneliti hal ini terjadi mungkin disebabkan karena jarak kelahiran subjek dengan anak selanjutnya termasuk kedalam jarak kelahiran yang kurang berisiko. Jarak kelahiran akan sangat berisiko bila ada faktor lain seperti ibu yang riwayat ASI tidak ekslusif, riwayat hipertensi, dan persediaan air yang tidak memenuhi syarat ataupun jumlah anak dalam keluarga yang mungkin berperan, dan belum diteliti, sehingga perlu dilakukan penelitian lebih lanjut.

Dalam penelitian ini dari 9 ibu yang mempunyai riwayat hipertensi saat hamil, terdapat $5 \quad(55,6 \%)$ ibu memiliki balita stunting. Faktanya dari 5 balita yang mengalami stunting terdapat faktor variabel lainnya yaitu 4 balita dengan faktor ASI tidak ekslusif. Satu balita dengan jarak kelahiran <2 tahun tidak terdapat hubungan yang bermakna antara riwayat hipertensi dengan kejadian stunting pada balita usia 24-36 bulan di wilayah kerja PuskesmasBanjar Agung tahun 2018. Menurut pendapat peneliti, bila hipertensi didapat bersamaan dengan faktor lain seperti ASI tidak eklsusif, dan jarak kelahiran yang dekat akan menyebabkan anak menjadi stunting. Saat ini ibu hamil yang mengalami hipertensi telah mendapatkan penanganan ibu hamil risiko tinggi dan rujukan risti sejak awal sehingga dampak yang mungkin timbul dapat di cegah.

Pada bayi, ASI sangat berperan dalam pemenuhan nutrisinya. Konsumsi ASI juga meningkatkan kekebalan tubuh bayi sehingga menurunkan penyakit infeksi. Sampai usia 6 bulan, bayi direkomendasikan hanya mengonsumsi Air Susu Ibu (ASI) Ekslusif. Memberikan ASI secara ekslusif sampai bayi berusia 6 bulan akan menjamin tercapainya pengembangan potensial kecerdasan anak secara optimal karena selain sebagai nutrisi yang ideal dengan komposisi yang tepat serta disesuaikan dengan kebutuhan bayi, ASI juga mengandung nutrisi khusus yang diperlukan otak bayi agar tumbuh optimal (Almatsier, 2011). 
Hasil penelitian ini sejalan dengan Paudel et al (2012) dan Hidayah (2013) bahwa pemberian ASI Eksklusif yang tidak sesuai atau anak yang tidak diberikan ASI Eksklusif berisiko mengalami stunting jauh lebih besar daripada yang diberikan ASI Eksklusif. Berdasarkan penelitian ini didapatkan hasil bahwa balita dengan riwayat ASI tidak ekslusif sebanyak 70 orang $(52,6 \%)$ mengalami stunting, dan balita dengan riwayat ASI ekslusif sebanyak 24 orang $(10,5 \%)$ mengalami stunting. Peneliti berpendapat bahwa mungkin terdapat faktor lain yang belum diteliti yang mempunyai kontribusi terhadap stunting balita, seperti gizi ibu saat menyusui, praktik pemberian makanan yang kurang tepat setelah bayi berusia lebih dari 6 bulan, dan faktor infeksi yang sering muncul pada balita. ada hubungan yang bermakna antara riwayat ASI tidak ekslusif dengan kejadian stunting pada balita usia 2436 bulan di wilayah kerja Puskesmas Banjar Agung tahun 2018.

Air bersih merupakan salah satu kebutuhan manusia untuk memenuhi standar kehidupan manusia secara sehat. Ketersediaan air bersih yang terjangkau dan berkelanjutan menjadi bagian terpenting bagi setiap individu baik yang tinggal di perkotaan maupun pedesaan (Alamsyah, 2013). Hasil penelitian ini sejalan dengan penelitian Oktarina dan Sudiarti (2013) bahwa keluarga yang memiliki sumber air minum yang tidak terlindung akan meningkatkan kejadian balita stunting sebesar 1.38 kali dibandingkan dengan keluarga yang memiliki sumber air minum yang terlindung. Peneliti berpendapat bahwa sumber air minum yang tidak memenuhi syarat merupakan salah satu faktor yang bisa mempengaruhi status kesehatan balita. Berdasarkan hasil penelitian ini ada hubungan yang bermakna antara persediaan air bersih yang tidak memenuhi syarat dengan kejadian stunting pada balita usia 24-36 bulan di wilayah kerja Puskesmas Banjar Agung tahun 2018.

Variabel dominan yang berhubungan dengan kejadian stunting adalah KEK pada ibu. Kemenkes RI (2016) menyatakan bahwa ibu hamil dengan KEK berisiko melahirkan BBLR yang jika tidak segera ditangani dengan baik akan berisiko mengalami stunting. Faktor sebelum kelahiran seperti gizi selama kehamilan dan faktor setelah kelahiran seperti asupan gizi anak saat masa pertumbuhan, sosial ekonomi, ASI Eksklusif, penyakit infeksi, pelayanan kesehatan dan berbagai faktor lainnya yang berkolaborasi pada level dan tingkat tertentu sehingga pada akhirnya menyebabkan kegagalan pertumbuhan linear (Fikawati dkk, 2017). Tingginya ibu yang mempunyai riwayat KEK saat hamil berhubungan dengan kejadian balita stunting bias disebabkan karena ibu dengan KEK tidak mempunyai asupan gizi yang baik sebelum hamil, serta selama kehamilannya. Peneliti berpendapat bahwa diperlukan pemantauan untuk semua ibu hamil, baik yang KEK maupun tidak KEK dalam hal pemenuhan asupan gizi yang tepat dan seimbang sehingga diharapkan pertumbuhan janin optimal sejak dalam kandungan. Diperlukan juga penyuluhan tentang pengasuhan yang tepat terhadap bayi dan anak balita

Jurnal Dunia Kesmas, Vol. 9 No. 3, Juli 2020, hal. 336-345 ISSN 2301-6604 (Print), ISSN 2549-3485 (Online) 
serta pemantauan tumbuh kembang balita, karena faktanya terdapat $36,7 \%$ balita yang tidak ASI ekslusif. Pemantauan ini dapat dilakukan secara efektif di posyandu, kelas ibu balita secara terpadu dan berkesinambungan untuk meningkatkan pengetahuan ibu bagaimana melakukan perawatan saat hamil, menyusui, serta perawatan bayi balita, mengingat $48.9 \%$ balita yang stunting memiliki ibu dengan riwayat pendidikan SMP. Peneliti berpendapat perencanaan kehamilan sangat penting ditekankan karena yang banyak terjadi dilapangan saat ini adalah ibu datang ke fasilitas pelayanan kesehatan sudah dalam keadaan hamil, sehingga risiko janin untuk mengalami kurang gizi sangat tinggi bila ibu sudah dalam keadaan KEK. Dukungan keluarga, kerjasama lintas program dan lintas sektoral dalam berbagai kebijakan sangat diperlukan untuk menjamin tercapainya penurunan KEK pada ibu hamil.

\section{KESIMPULAN}

Terdapat hubungan statistik antara riwayat kurang energi kronis pada ibu $(p=0.001, \quad \mathrm{OR}=16.1, \mathrm{CI}=5.9-43.9)$, tinggi badan ibu $(p=0.001$, OR 12.9, $\mathrm{CI}=3.6-46.9)$, usia ibu saat hamil $(p$ $=0,038 \mathrm{OR}=2,78, \mathrm{CI}=1.1-6.8)$, riwayat $\mathrm{BBLR}(p=0.001 \mathrm{OR}=14.1, \mathrm{CI}$ =2.9-66.4), riwayat ASI tidak Ekslusif ( $p=0.001 \mathrm{OR}=9.5, \mathrm{CI}=5.5$ 16.3) dan persediaan air bersih yang tidak memenuhi syarat $(p=0.001$ $\mathrm{OR}=8,98$, CI $=5.3-15.3)$. Riwayat kurang energi kronis pada ibu saat hamil merupakan faktor yang paling dominan terhadap kejadian balita stunting ( $\mathrm{OR}=12.6, \mathrm{CI}=3.9-40.8)$.

Jurnal Dunia Kesmas, Vol. 9 No. 3, Juli 2020, hal. 336-345 ISSN 2301-6604 (Print), ISSN 2549-3485 (Online) http://ejurnalmalahayati.ac.id/index.php/duniakesmas/index

\section{SARAN}

Saran penelitian ini adalah agar Puskesmas melakukan penanganan terhadap balita stunting, bekerjasama dengan lintas sektor terkait membuat komitmen yang mendukung kebijakan penundaan usia perkawinan $<20$ tahun, penerapan ASI ekslusif di wilayah kerja, perbaikan sanitasi lingkungan dan peningkatan akses air bersih bagi masyarakat.

\section{DAFTAR PUSTAKA}

Alamsyah, D., Muliawati, R., (2013). Pilar Dasar Ilmu Kesehatan Masyarakat, Nuha Medika, Yoygakarta.

Dewey, G., K., Begum, K., (2010). Why Stunting Matters. https : // www. fhi360.org /sites/ default/ files/ media/documents/Insight\%20$\% 20$ Why \% 20stunting\% 20matters\%20\% 28English\%29.pdf

Ergin et al., (2007). Nutritional status and risk factors of chronic malnutrition in children under five years of age in Aydin, a western city of Turkey. http://www.ncbi.nlm.nih.gov/pubmed/ 17990582

Fikawati S., Syafiq, A., Veratamala, A., ( 2017). Gizi anak dan remaja, Rajawali Press, depok

Fitri (2012). Berat Lahir Sebagai Faktor Dominan terjadinya Stunting pada Balita (12-59 Bulan) di Sumatera ( Analisis Data Riskesdas 2010) http://lib.ui.ac.id/file?file $=$ digital $/ 2029$ 8098-T30071-Fitri.pdf

Hidayah F, (2013). Asi Eksklusif sebagai Faktor Risiko Kejadian Stunting Pada Anak Usia 6-24 Bulan di Kota Yogyakarta.

Irwansyah, (2016) Kehamilan remaja dan kejadian stunting anak usia 6-23 bulan di Lombok Barat. BKM Journal of community Medicine and Public Health Volume 32 Nomor 6 Halaman $x x-x x$

Kementerian Kesehatan Republik Indonesia, (2016). Situasi Balita Pendek, Jakarta 
Oktarina, Z., Sudiarti, T., (2013). Faktor Risiko Stunting Pada Balita (24-59 Bulan) Di Sumatera. Jurnal Gigi dan Pangan, November 2013, 8(3): 175180

Paudel B, at al (2012). Risk Factors for Stinting among Children: a community Based Case Control Study in Nepal. https://www.ncbi.nlm.nih.Gov/pubme d/23434956

Sartono, (2016). Hubungan Kurang Energi Kronis Ibu Hamil Dengan Kejadian Stunting pada anak usia 6-24 Bulan Di Kota Yogyakarta, https://jurnal.ugm.ac.id/bkm/article/d ownload/8628/20618

Svepors P. at al (2016). Stunted at 10 Years. Linear Growht Trajectories and Stunting from Birth to Pre Adolescence in Rural Bangladesh Cohort, PLOS ONE. DOI: $10.1371 /$ journal.pone.0149700

Trihono dkk., (2015). Pendek (Stunting) di Indonesia, Masalah dan Solusinya. Badan Penelitian dan Pengembangan Kesehatan, Jakarta.

Victora, C.G., et al (2008). Maternal and Child Undernutrition: Conseqeunces for Adult Health and Human Capita. Lancet 2008; 371:340-57.https : // www.thelancet.com/action/showPdf?pi $\mathrm{i}=\mathrm{S} 01406736 \% 2807 \% 2961692-4 . \mathrm{pdf}$

WHO. (2010). Nutritional Landscape Information System (NLIS) Country Profile Indicators-Interpretion Guide. http: // www.who.int/nutition/ nils_ interpretation_guide.pdf 